\title{
On the status and position of Tian-Shanian populations of Paralasa cf. kusnezovi (Avinoff, 1910) (Lepidoptera: Satyridae)
}

\section{О статусе и положкении тян-шанских попуяяџий Paralasa cf. kusnezovi (Avinoff, 1910) (Lepidoptera: Satyridae)}

\author{
S.K. Korb ${ }^{1 *}$ Z.F. Fric ${ }^{2}$, A. Bartonova ${ }^{2}$ \\ С.К. Корбб, 3.Ф. Фрищ ${ }^{2}$ А. Бартонова ${ }^{2}$
}

\footnotetext{
${ }^{1}$ Russian Entomological Society, Nizhny Novgorod Branch, Russian Academy of Sciences, P.O.Box 97, Nizhny Novgorod, 603009 Russia. E-mail: stanislavkorb@list.ru

${ }^{1}$ Русское энтомологическое общество, Нижегородское отделение, а/я 97, г. Нижний Новгород 603009 Россия.

${ }^{2}$ Institute of Entomology, Biology Centre, Academy of Sciences of the Czech Republic, Branisovska 31, 370 05 Ceske Budejovice, Czech Republic. E-mail: zdfric@gmail.com
}

KEY WORDS: Paralasa kusnezovi, Tian-Shan, subspecies, taxonomy.

КЛЮЧЕВЫЕ СЛОВА: Paralasa kusnezovi, Тянь-Шань, подвиды, таксономия.

ABSTRACT. Using COI sequence, it is shown, that Paralasa kusnezovi bektur Korb, 2013 is an junior synonym of P. kusnezovi kusnezovi (Avinoff, 1910) syn.n., and that P. kusnezovi kolesnichenkoi Churkin et Zhdanko, 2001 has full-species rank: P. kolesnichenkoi Churkin et Zhdanko, 2001, stat.n.

РЕЗЮМЕ. С использованием последовательности гена COI показано, что Paralasa kusnezovi bektur Korb, 2013 является синонимом P. kusnezovi kusnezovi (Avinoff, 1910) syn.n., P. kusnezovi kolesnichenkoi Churkin et Zhdanko, 2001 рассматривается в качестве самостоятельного вида $P$. kolesnichenkoi Churkin et Zhdanko, 2001, stat.n.

\section{Introduction}

In 2012 the species complex of Paralasa jordana (Staudinger, 1882) was revised by S.V. Churkin, V.A. Pletnev [2012]. The main result of this paper was in merging of almost all Tian-Shanian representatives of this genus (including P. helios (O.Bang-Haas, 1927) and $P$. bogutena Lukhtanov et Lukhtanov, 1994) into one species with the oldest available name $P$. kusnezovi (Avinoff, 1910). This revision was criticised by the first author [Korb, 2013] in that point that the taxon $P$. bogutena is a separate species. The other unclear taxon in this group is P. kusnezovi kolesnichenkoi Churkin et Zhdanko, 2001, a very distinctive butterfly with intermediate characters between $P$. bogutena and P. kusnezovi.

$P$. bogutena without doubts occurs in eastern part of North Tian-Shan: mountain ridges Transilian Alatau, Terskey Ala-Too and Kungey Ala-Too. The spe-

* Corresponding author cies is also present in Boguty and Syugaty Mts. Its border from P. kusnezovi is in Boom valley between Kungey Ala-Too and Kirghizsky Mts. We sampled and sequenced one specimen from Kirghizsky Mts. to confirm this opinion. Also we sampled one specimen from Inner Tian-Shan, where the taxon kolesnichenkoi is present, to clarify its status and position.

\section{Materials and methods}

DNA was extracted using the Geneaid Genomic DNA Mini Kit, Tissue. 5P fragment of the Cytochrome C oxidase subunit I ("barcode region") was amplified using primers HybLCO and HybHCO according to protocols by Wahlberg and Wheat [2008]. PCR products were sequenced by Macrogen (Seoul, Korea) on an ABI capillary sequencer. The sequences were aligned in BioEdit ver. 7.0.9.0. For the calculations of tree, we used Maximum Likelihood with transition and transversion substitutions included, and with Gamma distributed heterogeneous rates in MEGA 6.

Two specimens were sequenced:

1 O P. kusnezovi bektur Korb, 2013: 30.07.2014, Kirghizia, Kirghizsky Mts., Ala-Archa Nature Reserve, 2400 m, leg. S.K. Korb (Figs 1-2).

$1 O^{7}$ P. kusnezovi kolesnichenkoi Churkin et Zhdanko, 2001: 9.07.2014, Kirghizia, Suusamyrtoo Mts., Kekemeren river valley $30 \mathrm{~km}$ S of settlement Kozhomkul, 1800 m, leg. S.K. Korb (Figs 3-4).

Both sequenced specimens will be transferred to the collection of Zoological Institute of the Russian Academy of Sciences (St.-Petersburg, Russia).

Comparative material was used from GenBank (see Fig. 1 for Accession Numbers) and was published by Lukhtanov et al. [2009]. 

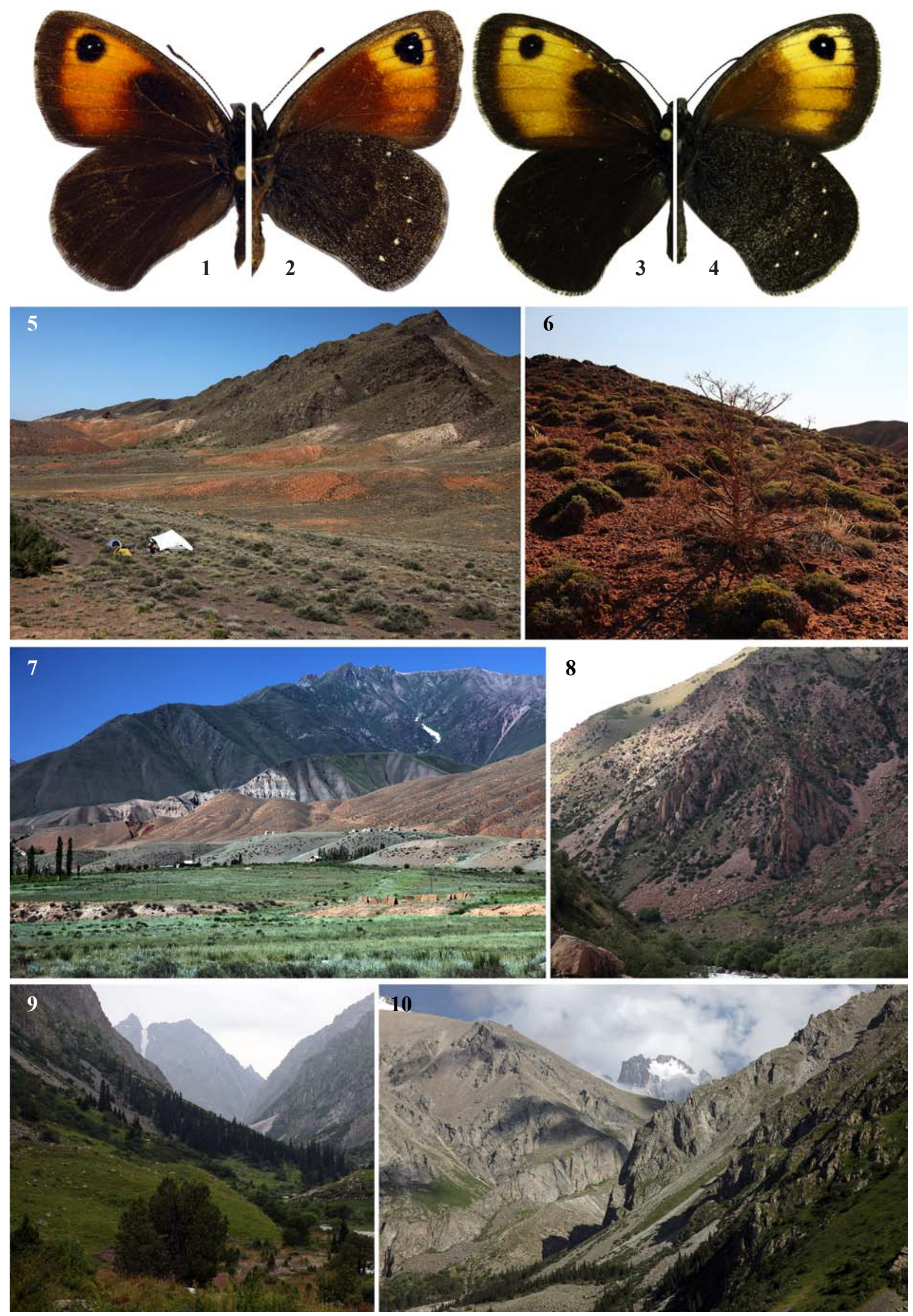


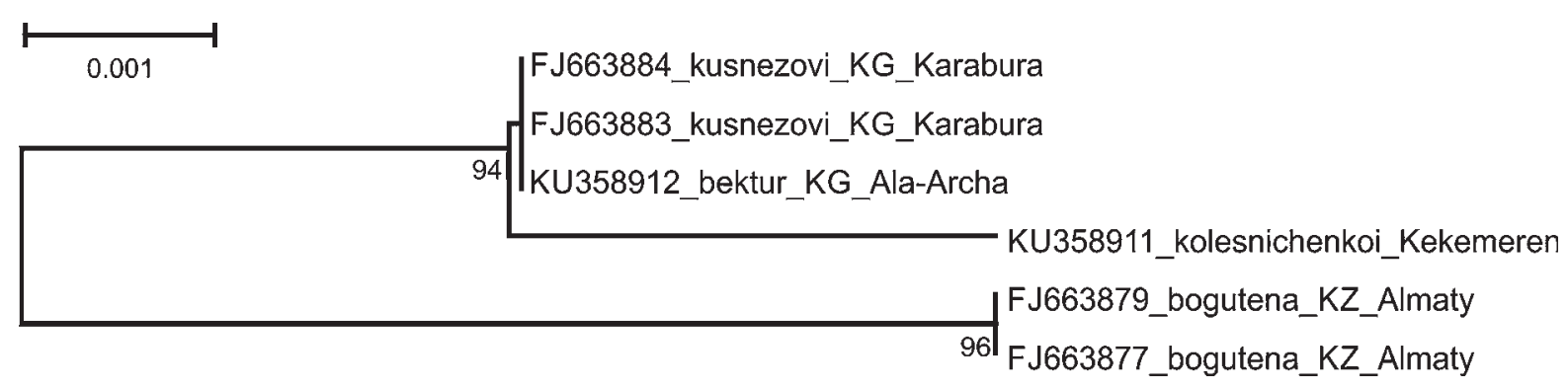

Fig. 11. Part of the ML-tree of the genus Paralasa, P. kusnezovi-related taxa (Kimura-2 parameter model, 10000 bootstrap-replications). Рис. 11. Фрагмент ML-дерева рода Paralasa, таксоны, родственные P. kusnezovi (Kimura-2 parameter model, 10000 bootstrapreplications).

\section{Results}

The differences in COI sequences between nominotypical population of $P$. kusnezovi from West TianShan (Karabura river valley, samples FJ663883, FJ663884) and the population described from Kirghizsky Mts. under the name P. kusnezovi bektur Korb, 2013, are less than $0.1 \%$ (Fig. 11). It means that both populations belong to the same subspecies, and thus $P$. kusnezovi kusnezovi (Avinoff, 1910) $=$ P. kusnezovi bektur Korb, 2013, syn.n.

The differences in COI sequences between nominotypical population of $P$. kusnezovi from West TianShan (Karabura river valley, samples FJ663883, FJ663884), population of $P$. bogutena from Almaty vicinities (samples FJ663877, FJ663879) and population of P. kusnezovi kolesnichenkoi from Suusamyrtoo Mts. are similarly high and clearly show that in fact we have three different species (Fig. 11). Thus the new status should be implemented: Paralasa kolesnichenkoi Churkin et Zhdanko, 2011, stat.n.

\section{Discussion}

The genus Paralasa has a wide Central Asiatic distribution. However, the distribution in Tian-Shanian territory is very local and sporadic. It is also very important to note that all the taxa inhabiting TianShanian mountains are similar to $P$. kusnezovi. The taxonomic situation within this genus cannot be in many cases resolved by only traditional morphologic methods. The wing pattern in this group is very conservative and mostly cannot be used for species separation. The genitalia morphology has never been studied in its variability, so far it was studied only on few samples without any statistical analysis. Only then it can be used as a tool for species differentiation. We did it for very limited amount of taxa [Korb, 2013] but a lot of work is still incomplete.

Most likely all these taxa we treat now as the separate species (P. kusnezovi, P. bogutena, P. kolesnichen$k o i)$ are young species which differ mainly in DNA (we checked the COI sequence) and biotope preferences (see below). The last differenciation should be described in details as in our opinion it is very important and can be presented as a good example of the cluster biodiversity of the multidimensional strategy [Korb et al., 2016].

Low-mountainous xerophylic habitat (600-1200 m) (Figs 5-6): P. bogutena. Butterflies inhabit xerophylic locations within low-mountainous biotopes (mostly deeply dissected valleys with red clay on its bottom: semideserts and deserts). These are very hot places, the peak day temperature can be easily $40-45^{\circ} \mathrm{C}$ in shadow.

Middle-mountainous xerophylic habitat (1600-2400 m) (Figs 7-8): P. kolesnichenkoi. Butterflies inhabit xerophylic locations within middle-mountainous biotopes (mostly red rocks in the steppe vertical zone). There are quite hot places, the peak day temperature can reach $30-35^{\circ} \mathrm{C}$ in shadow.

Middle- or high-mountainous mesophylic habitat (over 2000 m) (Figs 9-10): P. kusnezovi. Butterflies inhabit mesophilous locations within middle-mountainous and high-mountainous biotopes (mostly screes in the forest and meadow vertical zone). There are not hot places. The peak day temperature can reach $25-30^{\circ} \mathrm{C}$ in shadow.

ACKNOWLEDGMENTS. We are thankful to Dr S.Yu. Sinev and Dr A.L. Lvovsky (Zoological Institute of the Russian Academy of Sciences, St.-Petersburg, Russia), Dr W. Mey

Figs 1-10. Paralasa, males and biotopes: 1-2 - P. kusnezovi bektur; 3-4 - P. kusnezovi kolesnichenkoi; 5-6 - P. bogutena biotope, Kazakhstan, Boguty Mts., Chingilsu valley, N43 34.825' E78 ${ }^{\circ}$ 39.847', 800-1200 m; 7-8 - P. kolesnichenkoi biotope, Kirghizia, Suusamyrtoo Mts., Kekemeren river valley $30 \mathrm{~km} \mathrm{~S}$ of settlement Kozhomkul, N4155', E74¹0', 1800-2300 m; 9-10 — P. kusnezovi bektur biotope, Kirghizia, Kirghiz Mts., Ala-Archa Nature Reserve, N42³1', E74²9', 2400-3000 m.

Рис. 1-10. Paralasa, самцы и биотопы: 1-2 - P. kusnezovi bektur; 3-4 - P. kusnezovi kolesnichenkoi; 5-6 - биотоп P. bogutena: Казахстан, хр. Богуты, долина Чингилсу, N43 34.825' E78 39.847', 800-1200 м; 7-8 - биотоп P. kolesnichenkoi: Киргизия, хр. Сусамыр Тоо., долина р. Кекемерен 30 км Ю от пос. Кожомкул, N4155', E74²10', 1800-2300 м; 9-10 - биотоп P. kusnezovi bektur, Киргизия, хр. Киргиз, заповедник Ала-Арча, N42³1', E74²9’, 2400-3000 м. 
(Museum für Naturkunde, Berlin, Germany) for giving access to study of curated collections. The sequencing was supported by the Czech Science Foundation (GA CR) (14-36098G) and by the University of South Bohemia (168/2013/P).

\section{References}

Churkin S.V., Pletnev V.A. 2012. A review of the Paralasa jordanacomplex from Central Asia with descriptions of new taxa (Lepidoptera, Satyridae) // Atalanta. Vol.43. P.120-144.

Korb S.K. 2013. [New satyrid taxa from Central Asia (Lepidoptera, Satyridae)] // Eversmannia. Vol.33. P.10-16 [in Russian].
Korb S.K., Bolshakov L.V., Fric Z., Bartonova A. 2016. Cluster biodiversity as a multidimensional structure evolution strategy: checkerspot butterflies of the group Euphydryas aurinia (Rottemburg, 1775) (Lepidoptera: Nymphalidae) // Systematic Entomology. DOI: $10.1111 /$ syen.12167. $16 \mathrm{p}$.

Lukhtanov V.A., Sourakov A., Zakharov E.V., Hebert P.D.N. 2009. DNA barcoding Central Asian butterflies: increasing geographical dimension does not significantly reduce the success of species identification // Molecular ecology resources. Vol.9. P.1302-1310.

Wahlberg N., Wheat C.W. 2008. Genomic outposts serve the phylogenomic pioneers: designing novel nuclear markers for genomic DNA extractions of Lepidoptera // Systematic Biology. Vol.57. P.231-242. 